\title{
Letters
}

\section{Late lessons from Auschwitz-is there anything more to learn for the $21 \mathrm{st}$ century?}

SIR

A conference of philosophy of medicine in Crakow, August 2000, offered the opportunity to visit Auschwitz-an offer reluctantly accepted by the author who had two decades ago, spent some months in Israel, cried at Dachau, treated (in the course of consultant practice over three decades in oncology and palliative medicine) many holocaust survivors, and counts among close friends and colleagues persons profoundly affected by Auschwitz and associated activities. Surely, the visit would be simply a mark of respect, and an episode of further personal grieving maybe, but not enlightenment. This was not the case.

The lasting impression has been that of the dangers of efficiency as a value in itself, the inadequacy of outcome measures if the array is incomplete, and the need for clear articulation not only of goals, but of the presuppositions underlying the formulation of goals.

One does not need to explicate these points with reference to the holocaust, save to note that outcome measures related to saving of funds, accumulation of objects of material value, even perceived community benefits and achievement of specified goals, must all be subservient to outcome measures related to the good of the affected individual human persons. Efficiency and efficacy should not in themselves be accepted as goods (but may be); they have value only in the light of legitimate goals. What has this to do with contemporary medical practice?

For a start, outcome measures are prominent in policy formulation at health system level-and efficiency is (rightly) highly prized, especially where the use of expensive hospital resources is concerned. The concept of diagnosis related groupings (DRG) and guidelines concerning expectations of length of stay have dramatically influenced the profile of hospitals - structure, size and function.

In the hospital sector, outcome measures are being achieved: diminishing length of stay appears to be seen as a mark of excellence by administrators, insurers, funding authorities and many clinicians, and the efficiency of the use of hospital resources has vastly improved. All sorts of procedures previously presumed to need admission are now widely undertaken in ambulatory contexts.

It is in such situations, where outcome measures, related to the specified goals, are being efficiently achieved, that articulation and review of the underlying presuppositions may be necessary.

For the holocaust, and the Nazi elimination of handicapped and elderly persons prior to 1939 , the presupposition behind the specified goals appears to be that there are lives not worthy to be lived ${ }^{1}$ - framed by the concept that there is an acceptable view of a worthy human person-an ideal of the good. Such ideas were clearly the result of profound historical currents, as well as of the early 20 th century scientific, philosophical and political environment, with doctors (academic leaders and medical associations) in the vanguard as mainly non-resisting articulators of the ideas, as well as managers of the strategies to develop and achieve goals. ${ }^{2} 3$

For our great hospitals, what are the presuppositions in the midst of current changes? And are they acceptable? Or contestable?

First, it is fairly clear that, contrary to the role of hospitals in society in the past, hospitals are now places for antidisease interventions (in a human atmosphere) but not for care, except that care which is necessarily associated with therapeutic interventions.

Second, it is expected that patients and their families treated in hospitals by efficient interventions, compressed into as short a time as possible, will experience benefit: human flourishing of patients and their families will be facilitated by such efficient procedures.

Third, it is assumed that efficient use of hospital resources should permit funds to flow to other areas of the health care system to ensure that care is available for all in accordance with need.

There is need for debate concerning such presuppositions - as well as scrutiny of the array of outcome measures in place or necessary as part of the evaluation of a health system (especially hospitals) in contributing (efficiently) to human flourishing. Do we still have lessons to learn from Auschwitz?

\section{References}

1 Alexander L. Medical science under dictatorship. New England fournal of Medicine 1949;241:39-47.

2 Hanauski-Abel HM. Not a slippery slope or a sudden subversion: German medicine and National Socialism in 1933. British Medical fournal 1996; 313:1453-63.

3 Seidelman WE. Nuremberg lamentation: for the forgotten victims of medical science. British Medical fournal 1996;313:1463-6.

PROFESSOR J NORELLE LICKISS

Director, Sydney Institute of Palliative Medicine

Department of Palliative Care Royal Prince Alfred Hospital Missenden Road Camperdown NSW 2050 Australia

\section{Treatment of patients who are Jehovah's Witnesses}

SIR

I read with interest the recent articles by "Lee Elder" ${ }^{1}$ and O Muramoto, ${ }^{2}$ 
along with the accompanying editorial $^{3}$ about the treatment of patients who are Jehovah's Witnesses.

May I say that clinicans are well advised to discuss the specific, personal management options requested by each Jehovah's Witness; Witness patients will gladly outline their management preferences and their reasons for such.

On this point it might be timely to reiterate the guidelines issued by the Royal College of Surgeons": "It is not a doctor's job to question these principles, but they should discuss with Jehovah's Witness patients the medical consequences of non-transfusion in the management of their specific condition. It is essential to establish the views held by each Jehovah's Witness patient ...".

\section{References}

1 Elder L. Why some Jehovah's Witnesses accept blood and conscientiously reject official Watchtower Society blood policy. Fournal of Medical Ethics 2000;26:375.80

2 Muramoto O. Medical confidentiality and the protection of Jehovah's Witnesses' autonomous refusal of blood. Fournal of Medical Ethics 2000;26:381-

3 Gillon R. Refusal of potentially lifesaving blood transfusions by Jehovah's Witnesses: should doctors explain that not all JWs think it's religiously required?[editorial] fournal of Medical Ethics 2000;26:299-301.

4 The Royal College of Surgeons of England. Code of practice for the surgical management of fehovah's Witnesses. London: The Royal College of Surgeons of England, 1996: 1.

PAUL WADE

Director, Hospital Information Services for fehovah's Witnesses

Watchtower Bible and Tract Society of Britain, The Ridgeway

London NW7 1RN

\section{Jehovah's \\ Witnesses-the blood transfusion taboo}

SIR

There is nothing wrong with Dr Gillon's suggestion to doctors that they ask Jehovah's Witness patients why they refuse a blood transfusions and present alternative viewpoints. However, enforcing the argument with reference to fellow believers who do accept a transfusion will be perceived by many believers as a contradictio in terminis. Since the dualistic theology of the Jehovah's Witnesses hardly accommodates doctrinal ambivalence, any member who wilfully infringes basic teachings is simply considered a nonmember. ${ }^{2}$ Worse than that, the umbrella organisation will anathematise such an unrepentant transgressor and symbolically rank him or her with the persistent fool in Proverbs 26, who, "just like a dog, is returning to its own vomit". ${ }^{3}$ Viewed within this context, one may wonder about the advisability of referring to these and similar dissident opinions.

\section{References}

1 Gillon R. Refusal of potentially lifesaving blood transfusions by Jehovah's Witnesses: should doctors explain that not all JWs think it's religiously required? [editorial] fournal of Medical Ethics 2000;26:299-301.

2 Singelenberg R. The blood transfusion taboo of Jehovah's Witnesses: origin, development and function of a controversial doctrine. Social Science Medicine 1990;31:515-23. Reprinted in Thomasma DC, Marshall PA. Clinical medical thics Press of America, 1995: 297-309.

3 Holy Bible. Proverbs xvi, 11.

RICHARD SINGELENBERG

Department of Cultural Anthropology Faculty of Social Sciences Universiteit Utrecht PO Box 80140 3508 TC Utrecht The Netherlands 